\title{
Inflammatory islet damage in patients bearing HLA-DR 3 and/or DR 4 haplotypes does not lead to islet autoimmunity
}

\author{
E. F. Lampeter ${ }^{1}$, I.Seifert ${ }^{2}$, D. Lohmann ${ }^{2}$, J. W. Heise' ${ }^{3}$, J. Bertrams ${ }^{4}$, M. R. Christie ${ }^{5}$, V. Kolb-Bachofen ${ }^{6}$ H. Kolb \\ ${ }^{1}$ Diabetes Research Institute at the Heinrich-Heine-University, Düsseldorf, Germany \\ ${ }^{2}$ City Hospital, Leipzig, Germany \\ ${ }^{3}$ Department of Surgery, Heinrich-Heine-University, Düsseldorf, Germany \\ ${ }^{4}$ Department of Laboratory Medicine, Elisabeth Hospital, Essen, Germany \\ ${ }^{5}$ Nuffield Department of Clinical Biochemistry, John Radcliffe Hospital, Oxford, UK \\ ${ }^{6}$ Department of Immunology, Heinrich-Heine-University, Düsseldorf, Germany
}

Summary The hypothesis was tested that islet autoimmunity is induced by ongoing islet cell destruction in subjects with susceptibility genes HLA-DR 3 and/or DR 4. Sixty-one patients with confirmed chronic pancreatitis were analysed, 30 of whom expressed HLADR 3 and/or DR 4. Electron microscopy studies in 10 patients showed that the inflammatory process also affected islets, as recognisable from islet cell lysis, intrainsular fibrosis and immune cell infiltrates. None of the sera tested contained any of three markers of islet autoimmunity, ICA, IAA or GAD antibodies. A correlation was seen between the loss of exocrine function, as determined by the ALTAB-test, and of beta-cell function, as determined by the C-peptide response to i.v. glucagon. However, there was no preferential loss of beta-cell function in patients with HLA-DR 3 and/or DR 4. We conclude that islet cell destruction occurs during chronic pancreatitis, but does not trigger islet autoimmunity, even in the presence of HLA-DR 3 and/or DR 4. [Diabetologia (1994) 37: 471-475]

Key words IDDM, chronic pancreatitis, islet cell antibodies, autoimmunity.
Pancreatitis is associated with inflammatory changes of exocrine and also of endocrine tissue. These include the enhanced expression of HLA-A,B,C antigens on all cell types [1] and of HLA-class II antigens on nonendocrine cells, around and at the ductular pole of islets $[1,2]$. Macrophage and lymphocyte infiltrates and the progressive loss of exocrine and endocrine functions [3-5] indicate an inflammatory milieu which could promote autoantigen presentation and autoimmunity.

In autoimmune disease, persistent immune reactivity to self islet antigens is known to depend on the presence of appropriate disease susceptibility genes. In

Received: 18 August 1993 and in revised form: 17 November 1993

Corresponding author: Dr. E.F.Lampeter, Diabetes Research Institute, Auf'm Hennekamp 65, D-40225 Düsseldorf, Germany

Abbreviations: IDDM, Insulin-dependent diabetes mellitus; ICA, islet cell antibodies; IAA, insulin autoantibodies; GAD, glutamate decarboxylase; JDF, Juvenile Diabetes Foundation; PABA, N-acetyl-L-tyrosyl-paraaminobenzoic acid
IDDM a major contribution to genetic susceptibility comes from the HLA-D-region and is associated in Caucasians with HLA-DR 3 and/or DR 4 [6]. In addition HLA-DR 4 predisposes for insulin autoimmunity $[7,8]$.

In the present study we tested the hypothesis that presence of immune mediators and inflammatory cells in islets of Langerhans in individuals with genetic susceptibility to IDDM leads to autoimmunity towards beta cells in vivo. Such conditions are found in patients with chronic pancreatitis. The study includes morphology of pancreatic tissue, serological markers of antibeta-cell autoimmunity as well as functional tests of endocrine and exocrine function, all with respect to HLADR serotypes.

\section{Subjects and methods}

Sixty-one consecutive patients with chronic pancreatitis from the City Hospital Leipzig and the Department of Surgery at the University of Düsseldorf were included in the study. Chronic pancreatitis was diagnosed on the basis of typical clinical and biochemical signs, positive sonography, abdominal X-ray and/or endoscopic-retrograde-cholangio-pancreatico-graphy. 

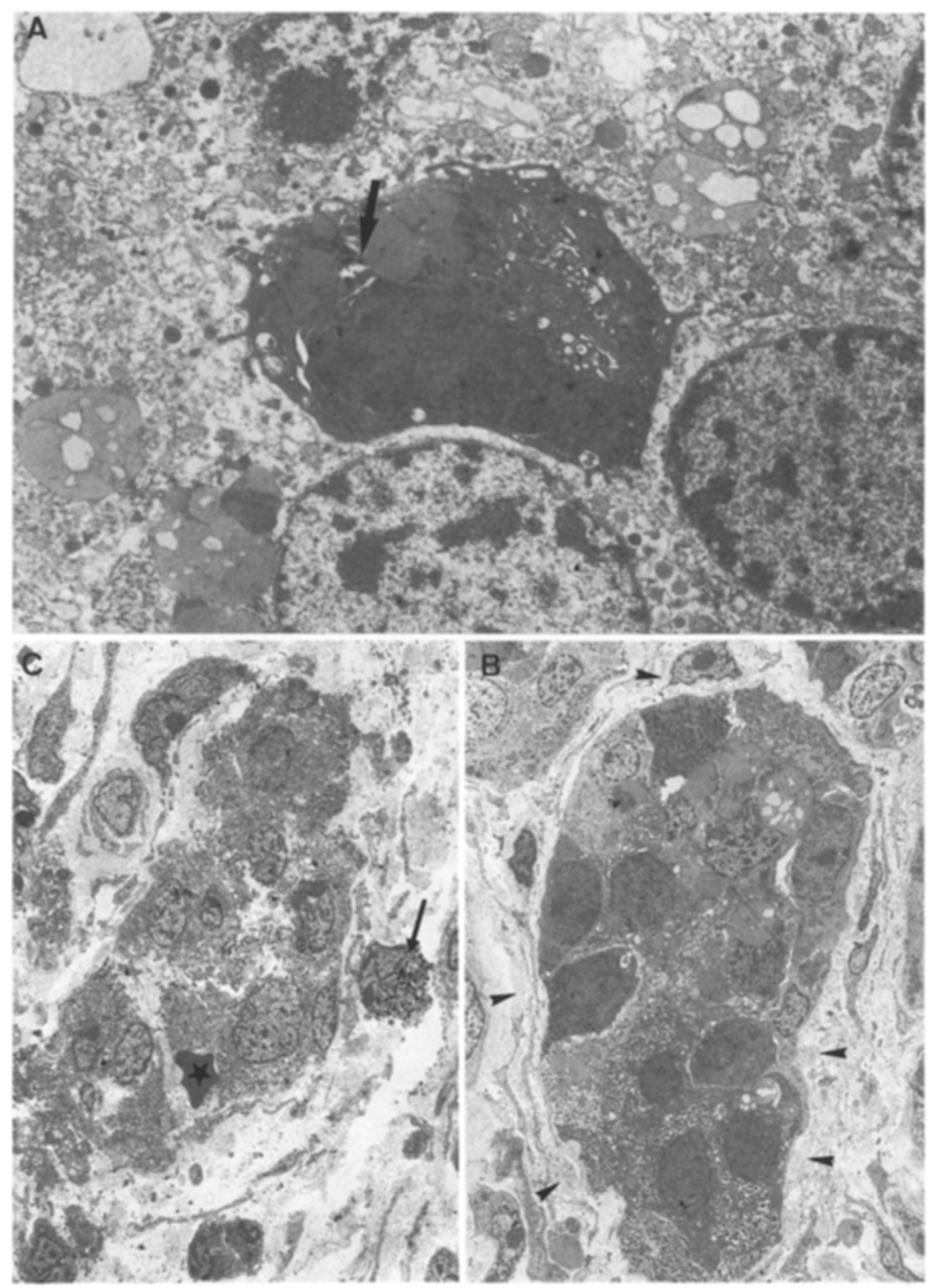

Fig.1 A-C. Electron micrographs from islets found within tissue resected from different pancreatitis patients.

A. Part of an islet from a male patient, aged 47 years. Islet cell lysis is evident from the absence of plasma membranes, swollen nuclei and loss of cytoplasm. Situated within the cell debris is a macrophage with a phagolysosome containing islet cell debris (arrow). Magnification: $8,050 \times$.

B Part of an islet from a female patient, aged 39 years. This part of a relatively intact islet is surrounded with fibrotic areas (arrowheads) containing many fibroblasts. The fibrotic areas dissect the islet into three parts. Magnification: $1,820 \times$. C. Islet remnant from a male patient, aged 29 years. Fibrotic area filled with islet cell debris is seen. At the left part an erythrocyte is found within the debris $\left(^{*}\right)$ outside of capillary beds as an indication of capillary breakdown. A mast cell is seen at the upper part of the micrograph (arrow). Magnification: 1,400 $\times$
Alcohol abuse was assumed if patients acknowledged regular consumption of more than $50 \mathrm{~g}$ alcohol per day, which was the case in 43 of 61 subjects. There was a male preponderance among patients ( 42 of 61 ), the mean age was 42.6 years (range 28-73). The mean duration of symptoms was $5.7 \pm 1.1$ years. In 22 patients partial pancreatectomy had been performed. Seven patients were using insulin and another seven patients had noninsulin dependent diabetes when studied. Transmission electron microscopy was performed on tissue from 10 patients at the University of Disseldorf. Tissue was fixed within $1 \mathrm{~min}$ after resection with $1.0 \%(\mathrm{v} / \mathrm{v})$ glutaraldehyde in cacodylate buffer ( $\mathrm{pH} 7.2$ ) containing $0.2 \mathrm{mmol} / /$ saccharose and $1 \mathrm{mmol} / \mathrm{l}$ $\mathrm{CaCl}_{2}$. Specimens were cut into small cubes, postfixed with $2.0 \%(\mathrm{w} / \mathrm{v}) \mathrm{OsO}_{4}$, dehydrated in a graded ethanol series and embedded in epoxy resin. To screen for islets in the plane of section, specimens were sectioned semithin and examined under light microscope after staining with toluidine blue prior to ultrathin sectioning. Ultrathin sectioned material was examined on a Philips EM 400 after staining with uranyl acetate and lead citrate [9].
Indirect immunofluorescence was used to measure ICA on sections of fresh frozen human pancreas of blood group 0 donors [10]. Results were expressed in JDF units using the ICA Workshop standard serum and values of 2.5 JDF units or more were considered positive. The ICA laboratory participates in ICA proficiency tests with continuous $100 \%$ specificity ratings [11]. IAA were measured by radioimmunoassay [12]. Antibodies to brain GAD were assayed according to the protocol described previously [13]. Cut-off for antibody positivity was $13 \%$ (2 SD above mean of 73 control sera).

Exocrine pancreatic function was measured by a modified ALTAB-test [14]. In brief, after exclusion of drug interference, intestinal malabsorption and decreased liver and kidney function, a liquid test meal followed by $2.0 \mathrm{~g}$ PABA was given. This was followed by oral administration of $250 \mathrm{ml}$ herbal tea immediately after and at 30,60 and $90 \mathrm{~min}$. Serum for PABA measurements were collected at $1,2,3$, and $6 \mathrm{~h}$. The 3 -h measurements were used for comparison. Exocrine functions were considered abnormal if the serum PABA level at $3 \mathrm{~h}$ was below $50.2 \mu \mathrm{mol} / 1$ (mean of 12 healthy control subjects $-2 \mathrm{SD}$ ). 


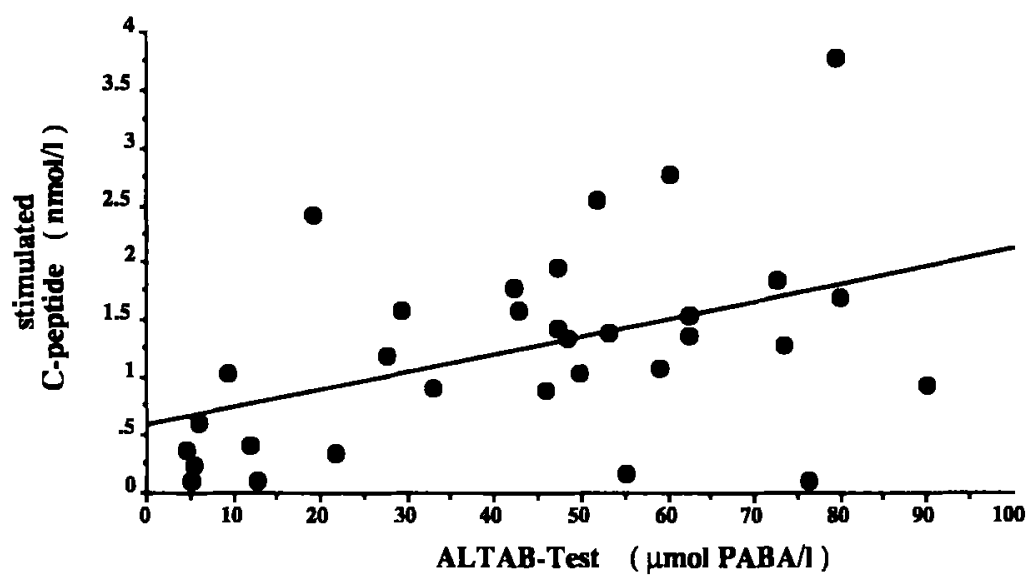

Fig.2. Correlation of residual exocrine and endocrine function in patients with chronic pancreatitis. Serum C-peptide was determined $7.5 \mathrm{~min}$ after $1 \mathrm{mg}$ glucagon i. v. . In the ALTAB-test serum analysis was performed $3 \mathrm{~h}$ after the administration of $2 \mathrm{~g}$ PABA

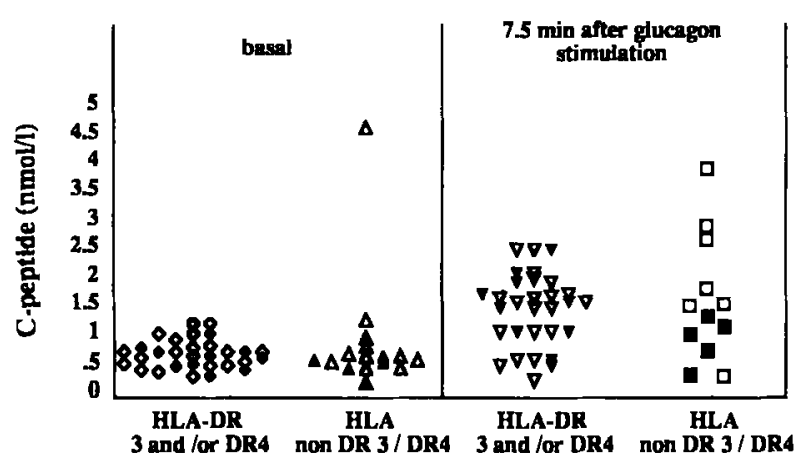

Fig. 3. C-peptide response (basal and $7.5 \mathrm{~min}$ after $1 \mathrm{mg}$ glucagon i.v.) in patients with chronic pancreatitis in relation to HLADR3/DR4. Data are shown of patients without pancreatic resection. Open symbols: patients with exocrine function in the normal range ( $>50.2 \mu \mathrm{mol} \mathrm{PABA} / \mathrm{l}$ at $3 \mathrm{~h}$ ); Filled symbols: patients with exocrine function below the normal range $(<50.2 \mu \mathrm{mol}$ $\mathrm{PABA} / \mathrm{l}$ at $3 \mathrm{~h}$ ) $p=\mathrm{NS}$ for comparison between patient groups at each time

Table 1. Clinical characteristics of the patients with chronic pancreatitis studied

\begin{tabular}{|c|c|c|}
\hline & $\begin{array}{l}\text { HLA-DR } \\
3 \text { and/or DR } 4\end{array}$ & $\begin{array}{l}\text { HLA-DR } \\
\text { non } 3 / 4\end{array}$ \\
\hline $\bar{n}$ & 30 & 31 \\
\hline Sex (male/female) & $19 / 11$ & $23 / 8$ \\
\hline Age (years) & $\begin{array}{l}41.4 \\
(29-60)\end{array}$ & $\begin{array}{l}48.5 \\
(28-73)\end{array}$ \\
\hline Duration of symptoms (years) & $4.5 \pm 1.0$ & $6.7 \pm 1.9$ \\
\hline $\begin{array}{l}\text { Patients with alcohol abuse } \\
\text { (> } 50 \mathrm{~g} / \text { day) } \\
\text { Patients with pancreas resection }\end{array}$ & $\begin{array}{r}19 \\
8\end{array}$ & $\begin{array}{l}17 \\
14\end{array}$ \\
\hline $\begin{array}{l}\text { ICA positive sera } \\
\text { ( }>0.13 \text { JDF units) }\end{array}$ & $0 / 30$ & $0 / 31$ \\
\hline $\begin{array}{l}\text { Insulin binding in } \\
\text { non-insulin-treated patients } \\
\text { (mU/ml serum) }\end{array}$ & $\begin{array}{l}0.14 \pm 0.02 \\
(n=30)\end{array}$ & $\begin{array}{l}0.17 \pm 0.03 \\
(n=23)\end{array}$ \\
\hline $\begin{array}{l}\text { IAA positive sera } \\
(\geq 0.81 \mu \mathrm{U} / \mathrm{ml})\end{array}$ & $0 / 25$ & $0 / 23$ \\
\hline $\begin{array}{l}\text { Anti-GAD positive sera } \\
\text { ( }>2 \text { SD of } 73 \text { normal sera) }\end{array}$ & $0 / 25$ & $0 / 20$ \\
\hline
\end{tabular}

Residual beta-cell function was tested by serum C-peptide concentration at baseline and $7.5 \mathrm{~min}$ after stimulation with $1 \mathrm{mg}$ glucagon i. v. . The cut-off level for significantly decreased C-peptide response was derived from nine age-matched healthy control subjects as $0.30 \mathrm{nmol} / \mathrm{h}$ at $0 \mathrm{~min}$ and $1.01 \mathrm{nmol} / \mathrm{l}$ at $7.5 \mathrm{~min}$ (mean-2 SD).

HLA-DR typing was performed by the standard microlymphocytotoxicity technique [15] with B lymphocytes enriched by nylon wool columns.

\section{Statistical analysis}

Chi-Square test with alpha and contingency correction or Student's $t$-test was performed as appropriate to test for statistical significance of differences among groups. Statview 512 + and StatWorks software on an Apple Macintosh computer were used.

\section{Results}

\section{Morphological analysis}

From 10 of the 61 patients with chronic pancreatitis pancreas tissue was available at the day of organ resection and was processed for electron microscopy. In these specimens 29 islets were recognised and examined by electron microscopy. Lysis of islet cells and presence of cellular infiltrates within the islets were observed in all pancreatic specimens (14 of 29 islets). Infiltrating cells displayed the characteristics of macrophages and were often found phagocytosing islet cell debris (Fig. 1 A). Mast cells were also frequently observed (Fig. 1C). Fibrosis and the presence of scar tissue within islets (Fig. 1B) were an indication of chronic destructive processes (10 of 29 islets from the 10 patients). This could also lead to complete breakdown of islet structure which is often accompanied by rupture of capillary beds, as indicated by erythrocytes found within tissue remnants (Fig. 1C). In total, 22 of 29 islets showed signs of morphological damage, such as cell lysis, macrophage infiltration, mast cell infiltration or fibrosis. 


\section{Islet specific autoimmunity}

All patients were typed for HLA antigens and grouped according to whether they were HLA-DR 3 and/or DR 4 or not (Table 1 ). None of the patients were found to be positive for ICA in either of the groups. In non-insulin-treated patients the binding of insulin by serum immunoglobulins was not different between the groups. None of the patients sera displayed an insulin binding capacity beyond 2 SD of 100 normal control sera, i. e. IAA could not be demonstrated (Table 1).

Antibodies against GAD were analysed in the sera of 45 patients. None contained detectable amounts of GAD antibodies (Table 1).

\section{Functional studies}

Residual exocrine and endocrine functions could be determined in 32 patients without tissue resection. There was a correlation $(p<0.05)$ between residual exocrine function as determined by the ALTAB-test and the stimulated C-peptide response to $1 \mathrm{mg}$ glucagon i.v. (Fig. 2).

When subjects whose ALTAB test was normal were further analysed, no significant difference was found between the groups who were either positive or negative for HLA-DR 3 and/or DR 4 when looking at stimulated $\mathrm{C}$-peptide responses in the glucagon tests $(1.3 \pm 0.1 \mathrm{nmol} / 1$ in $6 \mathrm{HLA}-\mathrm{DR} 3 \mathrm{and} /$ or DR 4 positive subjects vs. $2.0 \pm 0.4$ in 7 HLA-DR 3 and/or DR 4 negative patients, $p=$ NS) (Fig. 3).

\section{Discussion}

In the present study we tested the hypothesis that the presence of inflammatory cells and mediators within islets leads to autoimmune reactions against islet antigens in patients with appropriate genetic susceptibility. A natural model of this condition is chronic pancreatitis in subjects with HLA-DR 3 and/or DR 4. Chronic pancreatitis also affects the endocrine tissue, albeit lesions are much less marked. In general, there is a progressive loss of insulin producing cells and in the late stage of the disease there is also destruction of the total endocrine parenchyma [16]. Beta-cell damage is also evident from the loss of the C-peptide response to glucagon which we found to correlate with the loss of exocrine function, as previously described [17]. The presence of inflammatory macrophages within islets or other HLA class II positive cells in the vicinity of islets $[1,2]$ and the over-expression of HLA class I on islet cells [1] have been described previously.

The electron microscopic studies presented here confirm these light microscopy findings. The presence of phagocytosing macrophages beside mast cell infiltrates and collagen fibre deposition indicates chro- nicity of islet lesions. Taken together these findings favour the assumption that islet antigens are released during chronic pancreatitis. However, islet antigen release and probable presentation in the context of "diabetogenic" HLA-DR 3 and/or DR 4 was not sufficient to induce islet autoimmunity. None of the 61 patients sera analysed contained detectable amounts of ICA. An earlier study had found ICA in 2 of 22 patients with alcoholic pancreatitis but no information is available on antibody titre and family history of IDDM [18]. In contrast, in another study of 31 patients with chronic pancreatitis ICA were not detected in any of the patients [19]. The study was enlarged to include 113 patients and ICA were still not found [20].

The present work takes the analysis further by studying a cohort of HLA-DR typed patients with chronic pancreatitis including 31 individuals with HLA-DR 3 and/or DR 4. In addition, patient sera were analysed for other diabetes related autoantibodies and the relationship between exocrine and beta-cell damage in correlation to HLA type was determined. None of the non-insulin-treated patients had IAA in their serum. Background levels of IAA in sera of patients with or without HLA-DR 3 and/or DR 4 were comparable. HLA-DR 4 is the major gene complex predisposing for IAA [7, 8]. Another serum marker of islet autoimmunity, antibodies to GAD, were also not detected. In addition patients with HLA-DR 3 and/or DR 4 were analysed for early deterioration of beta-cell function as determined by the C-peptide response to i.v. glucagon. In patients whose exocrine function was still normal, stimulated C-peptide secretion was not different between subjects with or without HLA-DR 3 and/or DR 4.

The situation may be different when viral infections give rise to acute pancreatitis. Two cases of rotavirusinduced gastroenteritis and pancreatitis have been described where ICA were detectable [21]. Furthermore, in sub-clinical mumps pancreatitis ICA were found in 7 of 11 patients. Five of the patients who were HLA-DR 3 and/or DR 4 had reduced C-peptide levels for more than 3 years [22]. However, in such cases ICA production was still transient and later IDDM in general was not observed [23].

In conclusion, we show here that patients with chronic pancreatitis and HLA-DR 3 and/or DR4 do not develop islet autoimmunity and do not show accelerated loss of beta-cell function. These findings support that the contribution of the HLA region does not alone confer genetic susceptibility. Thus other genes separate from the HLA system or environmental triggers, or both must be active in the pathogenesis of IDDM.

Acknowledgements. This work was supported by grants from the Wilhelm Sander Stiftung (E. F. L., grant number 90.048.1), Neustadt a.d.Donau, Germany, and the Deutsche Diabetes Gesellschaft (E.F.L. Projektförderungspreis 1992). 


\section{References}

1. Pujol-Borrell R, Todd I, Doshi M, Gray D, Feldmann M, Bottazzo GF (1986) Differential expression and regulation of MHC products in the endocrine and exocrine cells of the human pancreas. Clin Exp Immunol. 65: 128-139

2. Forbes A, Schwarz G, Mirakian R et al. (1987) HLA antigens in chronic pancreatitis. Tissue Antigens 30: 176-183

3. Domschke S, Stock KP, Pichl J, Schneider MU, Domschke W (1985) Beta-cell reserve capacity in chronic pancreatitis. Hepatogastroenterology 32: 27-30

4. Amman RW, Buehler H, Muench R, Freiburghaus AW, Siegenthaler W (1987) Differences in the natural history of idiopathic (non-alcoholic) and alcoholic chronic pancreatitis. A comparative long-term study of 287 patients. Pancreas 2: 368-377

5. Bonora E, Rizzi C, Lesi C, Berra P, Coscelli C, Butturini U (1988) Insulin and C-peptide plasma levels in patients with severe chronic pancreatitis and fasting normoglycemia. Dig Dis Sci 33: 732-736

6. Sheehy MJ (1992) HLA and insulin-dependent diabetes: a protective perspective. Diabetes 41: 123-129

7. Ziegler R, Alper CA, Awdeh ZL et al. (1991) Specific association of HLA-DR4 with increased prevalence and level of insulin autoantibodies in first-degree relatives of patients with IDDM. Diabetes 40: 709-714

8. Ziegler AG, Standl E, Albert E, Mehnert H (1991) HLA-associated insulin autoantibody formation in newly diagnosed IDDM patients. Diabetes 40: 1146-1149

9. Hanenberg H, Kolb-Bachofen V, Kantwerk-Funke G, Kolb H (1989) Macrophage infiltration precedes and is a prerequisite for lymphocytic insulitis in pancreatic islets of pre-diabetic BB rats. Diabetologia 32: 126-134

10. Kolb H, Dannehl K, Grünklee D et al. (1988) Prospective analysis of islet cell antibodies in children with IDDM. Diabetologia 31: 189-194

11. Lernmark $\AA$, Molenaar JL, van Beers WAM et al. (1991) The Fourth International Serum Exchange Workshop to standardise cytoplasmic islet cell antibodies. Diabetologia 34: 534-535

12. Greenbaum C, Palmer JP, Kuglin B, Kolb H (1992) Insulin autoantibodies measured by RIA methodology are more re- lated to IDDM than those measured by ELISA. J Clin Endocrinol Metab 74: 1040-1044

13. Christie MR, Brown TJ, Cassidy D (1992) Binding of antibodies in sera from IDDM patients to glutamate decarboxylase from rat tissues. Evidence for antigenic and nonantigenic forms of the enzyme. Diabetologia 35: 380-384

14. Henker J, Sprossig C (1988) Specificity and sensitivity of the 4-N-acetyl-L-tyrosyl-p-aminobenzoic acid test in childhood with serum p-aminobenzoic acid determination. Dtsch Z Verdau Stoffwechselkr 48: 80-82

15. Terasaki PI, McClelland JD (1964) Microdroplet assay of human serum lymphocytotoxins. Nature 204: 990-1000

16. Gyr K, Heitz U, Beglinger C (1984) Pancreatitis. In: Klöppel G, Heitz PU, Gepts W (eds) Pancreatic pathology. Churchill Livingstone, Edinburgh London Melbourne New York, pp 44-72

17. Rageh W, Klugmann HJ, Schiedewitz W, Pohl A (1985) Der modifizierte ALTAB-Test in der Diagnostik der exokrinen Pankreasinsuffizienz. Dtsch Z Verdau Stoffwechselkr 45: 307-316

18. Bovo P, Mirakian R, Merigo F et al. (1987) HLA molecule expression on chronic pancreatitis specimens: Is there a role for autoimmunity? A preliminary study. Pancreas 2: 350-356

19. Larsen S, Hilsted J, Jakobsen BK, Svejgaard A, Marner B, Worning H (1990) Insulin-dependent diabetes mellitus secondary to chronic pancreatitis is not associated with HLA or the occurrence of islet-cell antibodies. J Immunogenet 17: 189-193

20. Marner B, Bille G, Christy M et al. (1991) Islet cell cytoplasmic antibodies (ICA) in diabetes and disorders of glucose tolerance. Diabetic Med 8: 812-816

21. Nigro G (1991) Pancreatitis with hypoglycemia-associated convulsions following rotavirus gastroenteritis. J Pediatr Gastroenterol Nutr 12: 280-282

22. Ludvigsson J, Forsberg P, Fryden A, Lindblom B, Marshall MO, von-Schenck H (1988) Mumps with laboratory signs of subclinical pancreatitis may cause a disturbed beta-cell function. Diabetes Res 9: 193-195

23. Helmke K, Otten A, Willems WR et al. (1986) Islet cell antibodies and the development of diabetes mellitus in relation to mumps infection and mumps vaccination. Diabetologia 29: $30-33$ 